\title{
An Aviation Strategy for Europe: A critical assessment of delivered results
}

\section{Anna Tomová1* ${ }^{*}$ Andrej Dudáš ${ }^{1}$}

\begin{abstract}
${ }^{1}$ Air Transport Department, Faculty of Operation and Economics of Transport and Communications, Žilina, Slovak Republic *Corresponding author: Air Transport Department, Faculty of Operation and Economics of Transport and Communications, Univerzitná 1, 01026 Žilina, Slovak Republic, Email: anna.tomova@fpedas.uniza.sk
\end{abstract}

\section{Abstract}

The paper critically evaluates the results of the European Commission set in "An Aviation Strategy for Europe" of 2015 in the form of the Indicative Action Plan. Balancing accomplished vs unaccomplished tasks across the fields of Common Aviation Policy and the legal nature of the tasks, the paper discusses broader context of the Common Aviation Policy of the European Union in light of eventual institutional and fiscal reform.

Keywords

aviation; strategy; European Union; European Commission

\section{Introduction}

The importance of aviation for European economy and society is well-known. The benefits of aviation for Europe are particularly seen in economic growth, employment, investment, technological progress, business innovations, social and economic coherence, and finally in the competitiveness of European economy in global scale. [1] On December 7, 2015 the European Commission issued the document named „An Aviation Strategy for Europe" in the form of Communication from the Commission to the European Parliament, the Council, the European Economic and Social Committee and the Committee of the Regions. The strategy sets as strategic priorities the following: an ambitious external aviation policy of the EU aimed at growth markets, tackling limits to growth both in the air and on the ground, maintaining high standards of aviation in the EU (both safety and security). The Commission also identified the need to strengthen social agenda in terms of aviation workers' conditions, to protect passenger rights, to promote new technologies and digital innovations and to con- tribute to high environmental standards. [2] The leading role of the European Commission in formulating the strategy is stemming from the nature of integration processes in the field of aviation within the European Union. As a supranational body of the European Union, the European Commission have been initiating necessary political measures and the respective legislation to replace fragmented national aviation markets by an integrated one. [3] The process started in the down-stream part of the industry and gradually continued in the up-stream part what has resulted in a comprehensive set of European regulations, directives, interpretative guidelines and other precepts of law. [4] Together with the formation of common market with air services within the European Union and the adoption of measures aimed at the creation of Single European Sky and more integrated system of airports in the European Union as well, the common external policy of the European Union was continuously shaped and thus, an exclusive autonomy of the European Union's member states was being limited and the European Commission was partially overtak- 
ing the role in the field. "An Aviation Strategy for Europe" elaborated by the European Commission is therefore a logical step which reflects a function of the European Commission as a mission - and - strategy - maker for the European Union as a whole. In this paper we shall critically assess the state of the art in terms of the time delivery of actions as they were set by the Indicative Action Plan within the strategy. Although the nature of the plan is explicitly labelled only as indicative, the pursuant of the plan may - on the other hand - indicate how the European Union is meeting its role in adopting and proposing new laws, preparing new laws and concluding the respective agreement with foreign countries or other regional integration groupings. In the final part of the paper, we shall discuss our findings about the time delivery of planned actions within the strategy as well as the newest ideas on a further aviation strategy for Europe.

\section{Delivering Planned Actions}

\subsection{Accomplished vs unaccomplished planned ac- tions}

The Aviation Strategy Indicative Action Plan was structured according to the phases in the adoption of the respective laws and/or international agreements. The respective time schedule covered the period between 2015 and 2019, and totally twenty-one actions were planned. Two actions were planned to be accomplished in 2015, while eight were planned to be accomplished in 2016. Thus, almost one half of the actions were scheduled to be carried out in the year when the strategy was announced or in a year after. In this context it could be expected that such schedule reflected the realistic knowledge of the European Commission and the sufficiency of information within the respective actions as they were set by the plan. In Table 1 we summarize the accomplishment of the planned actions as contained in the strategy at the date May 1, 2018.

As Table 1 informs, several of the tasks contained in the Aviation Strategy Indicative Action Plan were not accomplished. Within the tasks which were accomplished at March 1,2018 , there are several actions which were carried out later as it was originally set by the plan.

As Table 2 informs, domestic aviation policy's actions in the European Union seem to be harder to be carried out in comparison with the actions addressed to external aviation policy of the European Union. This can reflect still prevailing nationalism in domestic issues and accepted pan-European position in external aviation issues.

Within the respective aviation policies, just Single European Sky's progress sounds as the most critical in terms of creating Single European Aviation Market which would involve into the single system the up-stream components of aviation markets. Similarly, all actions within the block of "completion of inter-institutional process" have not been accomplished at May 1, 2018 what indicates the conflict between the supranational European Commission leading and other inter-governmental bodies within the European Union which are held liable for the approval of the respective Union's law.
Table 1. The accomplishment of the Aviation Strategy Indicative Action Plan (at May 1, 2018) Source: Own compilation

\begin{tabular}{|c|c|c|}
\hline \multicolumn{3}{|l|}{ Completion of Inter-Institutional Process } \\
\hline Planned action & $\begin{array}{l}\text { Scheduled } \\
\text { year of deliv- } \\
\text { ery }\end{array}$ & $\begin{array}{l}\text { Accomplished } \\
\text { yes } \quad / \text { no } \\
\text { /not relevant }\end{array}$ \\
\hline Revision of Slot Regulation $545 / 2009$ & 2016 & - \\
\hline Revision of Regulation 261/2004 on passenger rights & 2016 & . \\
\hline SES2+: Revision of Single European Sky framework & 2016 & - \\
\hline $\begin{array}{l}\text { Conclusion of the ratification process of EU accession protocol to Euro- } \\
\text { control }\end{array}$ & 2016-17 & - \\
\hline \multicolumn{3}{|l|}{ Commission Legislative Proposals } \\
\hline $\begin{array}{l}\text { Revision of basic aviation safety regulation 216/2008 including intro- } \\
\text { duction of provisions on drones }\end{array}$ & 2015 & $\checkmark$ \\
\hline Measures to address unfair practices (revision Regulation 868/2004) & 2016 & $\checkmark$ \\
\hline \multicolumn{3}{|l|}{ Commission Implementing Acts } \\
\hline $\begin{array}{l}\text { Revision of the air traffic management network functions, including the } \\
\text { selection of the Network Manager }\end{array}$ & 2017 & \\
\hline Revision of performance scheme (gate-to-gate) & 2019 & not relevant \\
\hline \multicolumn{3}{|l|}{ International Dimension } \\
\hline $\begin{array}{l}\text { Authorisation to negotiate comprehensive EU level air transport agree- } \\
\text { ments }\end{array}$ & 2015 & $\checkmark$ \\
\hline $\begin{array}{l}\text { Authorisation to negotiate bilateral Air Safety Agreements with China } \\
\text { and Japan }\end{array}$ & 2016 & $\checkmark$ \\
\hline Launch of new aviation dialogues with key partners & 2016-17 & $\checkmark$ \\
\hline \multicolumn{3}{|l|}{ Guidance Documents } \\
\hline Guidelines on passenger rights & 2016 & $\checkmark$ \\
\hline Guidelines on ownership and control & 2016 & $\checkmark$ \\
\hline Guidelines on Public Service Obligations & 2016 & 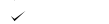 \\
\hline Best practices in minimum service levels in airspace management & 2016-17 & $\checkmark$ \\
\hline \multicolumn{3}{|l|}{ Fitness Check (REFIT) } \\
\hline $\begin{array}{l}\text { Computerised Reservation System (CRS) code of conduct on the distri- } \\
\text { bution of airline product }\end{array}$ & 2018 & not relevant \\
\hline \multicolumn{3}{|l|}{ Studies and Evaluations } \\
\hline Regulation $1008 / 2008$ on common rules for the operation of air services & $2017-18$ & not relevant \\
\hline $\begin{array}{l}\text { Regulation } 996 / 2010 \text { on aviation accident investigation } \\
\text { Ret }\end{array}$ & 2016-17 & - $\quad$ (started) \\
\hline Regulation $2111 / 2005$ on the EU airlines safety lists & 2016-17 & - $\quad$ (started) \\
\hline Airport Charges Directive 2009/12/EC & 2016-17 & $\checkmark \quad$ matcus \\
\hline Groundhandling services Directive 96/67/EC & 2017 & - \\
\hline
\end{tabular}

Table 2. The allocation of the accomplished vs unaccomplished actions according to the fields of the EU common aviation policy (at March 1, 2018) Source: Own compilation.

\begin{tabular}{|c|c|c|}
\hline & Accomplished & Unaccomplished \\
\hline $\begin{array}{l}\text { EU internal } \\
\text { market includ- } \\
\text { ing passenger } \\
\text { rights }\end{array}$ & $\begin{array}{l}\text { Airport Charges Directive 2009/12/EC } \\
\text { (study//evaluation) } \cdot \text { Guidelines on owner- } \\
\text { ship and control } \text {. Guidelines on Public } \\
\text { Services Obligations . Revision of Slot } \\
\text { Regulation } 545 / 2009 \text {. Revision of Reg- } \\
\text { ulation } 261 / 2004 \text { on passenger rights }\end{array}$ & $\begin{array}{l}\text { Revision of Slot Regulation 545/2009 } \\
\text { Revision of Regulation 261/2004 on pas- } \\
\text { senger rights . Groundhandling services } \\
\text { Directive 96/67/EC (study/evaluation) }\end{array}$ \\
\hline $\begin{array}{l}\text { External avia- } \\
\text { tion policy }\end{array}$ & $\begin{array}{l}\text { Authorisation to negotiate comprehen- } \\
\text { sive EU level air transport agreements } \\
\text { Authorisation to negotiate bilateral Air } \\
\text { Safety Agreements with China and Japan } \\
\text { Launch of new aviation dialogues with } \\
\text { key partners }\end{array}$ & \\
\hline $\begin{array}{l}\text { Single Euro- } \\
\text { pean Sky }\end{array}$ & $\begin{array}{l}\text { Best practices in minimum service levels } \\
\text { in airspace management }\end{array}$ & $\begin{array}{l}\text { Revision of the air traffic management } \\
\text { network functions, including the selection } \\
\text { of the Network Manager . SES2+: Re- } \\
\text { vision of Single European Sky framework } \\
\text {. Conclusion of the ratification process of } \\
\text { EU accession protocol to Eurocontrol }\end{array}$ \\
\hline \multicolumn{3}{|l|}{$\begin{array}{l}\text { Environmental } \\
\text { regulation }\end{array}$} \\
\hline $\begin{array}{l}\text { Aviation } \\
\text { safety and } \\
\text { security } \\
\text { policy }\end{array}$ & $\begin{array}{l}\text { Revision of basic aviation safety regu- } \\
\text { lation } 216 / 2008 \text { including introduction of } \\
\text { provisions on drones . Measures to ad- } \\
\text { dress unfair practices (revision Regulation } \\
868 / 2004 \text { ) }\end{array}$ & $\begin{array}{l}\text { - Regulation } 2111 / 2005 \text { on the EU airlines } \\
\text { safety lists (study/evaluation); (started) } \\
\quad \text { Regulation 996/2010 on aviation } \\
\text { accident investigation (study/evaluation); } \\
\text { (started) }\end{array}$ \\
\hline
\end{tabular}


This conflict delays the passage of the respective law. All actions within the block of "completion of inter-institutional process" are currently deadlocked. On the other hand, the European Commission in principle accomplished the actions which are not required to go through the strict official legal approval's procedure within the respective bodies of the European Union such as evaluation, studies, and guidance documents.

\subsection{Accomplished actions: What has been delivered?}

In the field of new proposals, the Proposal for a Regulation of the European Parliament and of the Council on common rules in the field of civil aviation and establishing a European Union Aviation Safety Agency, and repealing Regulation (EC) No 216/2008 of the European Parliament and of the Council was prepared. The Regulation (EC) 216/2008 of the European Parliament and of the Council on common rules in the field of civil aviation and establishing a European Aviation Safety Agency and repealing Council Directive 91/670/EEC, Regulation (EC) 1592/2002 and Directive 2004/36/EC is known as „Basic EASA Regulation“. [5] The proposal of a new „Basic EASA Regulation“ revises the scope of the common rules, introducing ground essential safety requirements for ground handling services, strengthening the EASA's competencies and adding other rules leading to better safety. The proposed regulation includes a basic legal framework for the safe development of drone operations in the EU. [6] After inter-institutional negotiations, the text has now to be formally approved by the Parliament as a whole and the Council in June, 2018. Moreover, the Commission opened in April 2018 also a public consultation process for developing more detailed rules on drones. [7]

Within legislative proposals, the Commission presented the package „Open and Connected Aviation“ that includes several legislative proposals, including the legislative proposal for regulation on safeguarding competition in air transport, repealing Regulation 868/2004. [8] Although the aim of the current Regulation (EC) 868/2004 of the Parliament and of the Council concerning protection against and unfair pricing practices causing injury to Community air carriers in the supply of air services from countries not members of the European Community was to protect the EU's air carriers, it showed itself as impracticable. The proposal for the Regulation of the European Parliament and of the Council on safeguarding competition in air transport, repealing Regulation (EC) No $868 / 2004$ lays down the rules on the conduct of investigations by the Commission and on the adoption of measures, relating to violation of applicable international obligations and to practices affecting competition between Union carriers and other carriers and causing or threatening to cause injury to Union air carriers. The proposal proposes that an investigation of such cases may be initiated on the basis of Member State, an EU air carrier or an association of EU air carriers and on the Commission's own initiative. The proposal contains the rules for the possibility to take financial or operational measures to offset injury or threat of injury. The Parliament's Committee of Transport and Tourism in its report supported the Commission's proposal of the regulation. [9]

In the field of international dimension, on 7 June 2016 the Council adopted mandates that allow the Commission to start negotiations on the air transport agreements (ATA) with four key partners. [10] The negotiating partners in four separate negotiations are the Association of Southeast Asian Nations (ASEAN), Qatar, the United Arab Emirates and Turkey. The agreement with ASEAN will become the first EU grouping to grouping aviation agreement. On 18-19 April 2018, the negotiations round of 4th Consultative Meeting on the comprehensive air service agreement between the EU and Qatar held what demonstrates launching new dialogues with key aviation partners. [11] On 1 December 2016, the Council adopted a mandate that will enable the Commission to start negotiations on a comprehensive air transport agreement with Armenia and the talks have started. [12] Three months after the adoption of ,Aviation Strategy“, the Council authorised the European Commission to open negotiations with China and Japan in view of concluding Bilateral Air Safety Agreements (BASA). [13]

In the field of guidance materials, all tasks were accomplished. In the form of the Commission notice, the Interpretative Guidelines on Regulation (EC) 261/2004 (of the European Parliament and of the Council establishing common rules on compensation and assistance to passengers in the event of denied boarding and of cancellation or long delay of flights and on Council Regulation (EC) No 2027/97 on air carrier liability in the event of accidents as amended by Regulation (EC) No 889/2002 of the European Parliament and of the Council) were officially published on 15 June, 2016. The rules are intended to explain more clearly a number of provisions contained in the regulation. The guidelines also relates to the Convention for the Unification of Certain Rules for International Carriage by Air (the Montreal Convention). The interpretative guidelines ought to ensure better application of the existing regulation on the protection of passenger rights. [14]

On 6 June, 2016 the interpretative guidelines on Regulation (EC) 1008/2008 named the Rules on Ownership and Control of EU air carriers were adopted in the form of the Commission's notice. The guidelines contain criteria along which ownership and control of carriers shall be assessed. The guidelines do not change the current rules contained in the Regulation (EC) No 1008/2008 of the European Parliament and of the Council on common rules for the operation of air services in the Community. The interpretative guidelines accentuate the need to focus on the nationality of the final natural persons owning the airline. They also provide guidance on how to assess situations where the EU airline belongs to an intermediate company or when the shares of the EU airline are on the stock exchange market. The guidelines also provide details on the four criteria mainly used by the Commission with regard to the effective control of the EU airlines. They 
consist in the assessment of the corporate governance of the EU airline, the shareholders rights, the financial links and the commercial cooperation of the non-EU investor with the EU airline. [15]

On 8 June 2017, the European Commission issued interpretative guidelines on Regulation (EC) 1008/2008 named the Rules on Ownership and Control of EU air carriers The guidelines do not amend Regulation 1008/2008 but explain more the rules for the provision of public service obligations under the scheme of PSO (type of service, types of routes, the vital importance of the route for the economic and social development, the bundling of routes, links with the slot regulation, the necessity and adequacy of the PSO, air fares, other conditions of PSO, type of obligations, tender procedures of PSO, state aid, etc.). [16]

On June 8 2017, the European Commission issued the Commission Staff Working Document named Practices favouring Air Traffic Management Services Continuity. The document contains practices which could ensure the continuity of air traffic management services in the event of strikes of the respective staff. The document refers to the findings of the Study on Options for ATM Service Continuity in the Event of Strikes, emphasizing the importance of social dialogue in air navigation service undertakings, summarizing the practices which favour air traffic management service continuity and other actions at the EU level. [17]

With regard to studies and evaluations, the European Commission initiated the ex-post evaluation of Directive 2009/12/EC on Airport Charges. The Support study to the Ex-post evaluation of Directive 2009/12/EC on Airport Charges was delivered by Steer Davies Gleave in 2017. The study brought several findings on better application of the Directive in terms of consultancy process, independent supervisory authorities, airport's investment, airport's competition and regulation of charges. Just the issue of charges' regulation vs liberalisation seems to be among crucial topics to achieve an integrated system of airports in the European Union. [18] In 2018, the European Commission made statement of the public consultation on charges for the use of airport infrastructure. [19]

On 5 July 2017, the European Commission launched an evaluation of Regulation (EC) 996/2010 of the European Parliament and of the Council on the investigation and prevention of accidents and incidents in civil aviation and repealing Directive 94/56/EC. [20] However, no findings of the evaluation have been delivered so far. Similarly, the Evaluation of Regulation 2111/2005 on the establishment of a Community list of air carrier subject to an operating ban in the Community was launched to be completed in 2017 , and also the public consultation on the "Black List of Airlines Regulation" was realized in 2017. [21] No evaluation report and/or study of the European Commission were detected by us in this regard.

\section{Conclusion}

The assessed pursuant of tasks stated in the Indicative Action plan of An Aviation Strategy of Europe brought as a main result the stand of between accomplished vs unaccomplished tasks. Such banausic approach, however, could lead to infirm conclusions. In general, "An Aviation Strategy for Europe" has been highly needed for the progress of civil aviation in the European Union in 21st century and therefore the existence of the document itself is better than "no strategy" scenario. On the other hand, tasks which were scheduled to be accomplished in 2016 and 2017 years prevail in the action plan and many of them had been already initiated earlier. Moreover, the time schedule of the tasks is not going over 2018. Thus, the European Commission only "copied" their "active" working agenda and inserted it in the plan. Therefore, such tasks in the action plan did not bring "new wings" of necessary strategic structural changes. It is at least debatable why the proposals of new regulations which have been blocked within interinstitutional process are among the tasks of the action plan. This aspect reveals the conflict between inter-governmental and supranational institutions of the European Union and also disproportional unrealistic expectations of the European Commission to change the status quo. In terms of the fields of common aviation policy, domestic aviation' issues are harder to be carried out in comparison with the actions addressed to external aviation policy of the European Union. This reveals nationalism in domestic issues which prevails at member States and pan-European position in external aviation issues accepted by Member States. We label this as "composition conflict". Our evaluation points at lagging behind in the Single European Sky's progress. This finding together with other laggings behind in airport's issues is seen by us as "vertical conflict". On the other hand, the European Commission in principle accomplished the majority of actions which are not required to go through the strict official legal approval's procedure within the respective bodies of the European Union such as evaluation, studies, and guidance documents. This positive result may be objected by the fact that the regulations ever needed gaping guidance and explanatory rules to cope with interpretation problems, misunderstandings and ambiguities in practise. In this context, a question sounds whether these could not be at least partially anticipated by the text of the regulation themselves. According to our opinion, the language of the evaluated strategy is symptomatic for the European Commission and well-known statements dominate in the text of the strategy. The strategy lacks a more visionary approach supported by strict goals and strategic aiming in a longer time perspective. Such aiming embodied in a new aviation strategy ought to outline the future architecture of civil aviation of the European Union at 2050. The design of such architecture will be dependent on institutional and fiscal reform of the European Union. The continuation of current status quo will be without any doubt a process supporting the triad of conflicts we named in this paper. Till the reform of the European Union will not be realized, the progress of civil aviation in the European Union will be decelerated and blocked by vertical, composition and inter-institutional conflicts pertaining to current civil aviation policy. In spite of 
the objections against the strategy, we must acknowledge that just the European Union has achieved the highest level of integration in aviation all over the world and its experiences, both positive and negative, are very precious for other regional integration groupings. The pioneering role of the EU in this regard is indubitable and the road taken by the EU to integrate civil aviation within the grouping is tried and tested as one of possible options.

\section{Acknowledgments}

This paper is a scientific output of the project VEGA No. 1/0006/17 Economic integration of European airspace as a structural and regulatory issue. The project has been supported by the grant scheme VEGA belonging to the Ministry of Education, Science, Research and Sport of the Slovak Republic.

\section{References}

[1] ACI Europe. Europe's airports. Economic impact - theory and the practice, 2015. URL https: / / centreforaviation.com/analysis/ reports/europes-airports-economicimpact--the-theory-and-the-practiceaci-europe-report-part-1-207594.

[2] EUROPEAN COMMISSION. Communication from the commission to the european parliament, the council, the european economic and social committee and the committee of the regions. an aviation strategy for europe, 2015. URL https://eur-lex.europa.eu/legalcontent/EN/TXT/PDF/?uri=CELEX: 52015DC0598\& from $=\mathrm{EN}$.

[3] A Tomová. The need for new directions in airspace economics: Seventy years after chicago. Journal of Air Transport Management, , 44, 2015.

[4] Sedláčková A. Novák A. Medzinárodnoprávna úprava civilného letectva. Žilinská univerzita v Žiline, 2010.

[5] Proposal for a regulation of the european parliament and of the council on common rules in the field of civil aviation and establishing a european union aviation safety agency, and repealing regulation (ec) no 216/2008 of the european parliament and of the council. 2015., 2015. URL https: / / eur-lex.europa.eu/resource.html? uri=cellar: da 8 dfec1-9ce9-11e5-8781$01 \mathrm{aa} 75 \mathrm{ed} 71 \mathrm{a} 1.0001 .02 / \mathrm{DOC} \_1 \&$ format $=\mathrm{PDF}$.

[6] European Aviation Safety Agency. Introduction of a regulatory framework for the operation of unmanned aircraft systems in the "open" and "specific" categories, 2018. URL https://www.easa.europa.eu/sites/ default/files/dfu/Opinion\%20No20012018 .pdf.
[7] EUROPEAN COMMISSION. Public consultation on drones (unmanned aircraft) - technical standards for drones as a product and conditions for drone operations, 2018. URL https : / / ec . europa . eu/info/ consultations/2018-drones_en.

[8] EUROPEAN COMMISSION. Proposal for a regulation of the european parliament and the council on safeguarding competition in air transport, repealing regulation (ec) no 868/2004, 2017. URL https://ec.europa.eu/transport/sites / transport/files/com20170289-proposalregulation-safeguarding-competitionair-transport.pdf.

[9] EUROPEAN PARLIAMENT. Safeguarding competition in air transport, 2017. URL http: / / www . europarl . europa.eu/RegData/etudes/BRIE/2017/ $608689 /$ EPRS_BRI (2017)608689_EN.pdf.

[10] COUNCIL OF THE EUROPOEAN UNION. Comprehensive eu air transport agreements: Council adopts mandates, 2017. URL http://www. consilium. europa. eu/en/press/pressreleases/2016/06/07/comprehensive-euair-transport-agreements/.

[11] The PENINSULA: QATAR's Daily Newspaper. Qatar discusses comprehensive air-services agreement with eu, 2018. URL https:// thepeninsulaqatar.com/article/21/04/ 2018 /Qatar-discusses-ComprehensiveAir-Services-Agreement-with-EU.

[12] Delegation of the European Union to Armenia. Euarmenia talks on comprehensive air transport agreement kick-off in yerevan, 2017. URL https://eeas. europa.eu/delegations/armenia/25160/ eu-armenia-talks-comprehensive-airtransport-agreement-kick-yerevan_en.

[13] EUROPEAN COMMISSION. Aviation: Eu to launch negotiations with china and japan for new safety agreement, 2016. URL https: / / ec.europa.eu/ transport/modes/air/news/2016-03-08china-japan-safety-agreements_en.

[14] EUROPEAN COMMISSION. Commission notice. interpretative guidelines on regulation (ec) no 261/2004 of the european parliament and of the council establishing common rules on compensation and assistance to passengers in the event of denied boarding and of cancellation or long delay of flights and on council regulation (ec) no 2027/97 on air carrier liability in the event of accidents as amended by regulation (ec) no 889/2002 of the european parliament and of the council, 2016. URL https://eur-lex.europa.eu/legalcontent/EN/TXT/PDF / ?uri=CELEX: $52016 \mathrm{XC0} 615(01)$ \& from=EN. 
[15] EUROPEAN COMMISSION. Commission notice. interpretative guidelines on regulation (ec) 1008/2008 - rules on ownership and control of eu air carriers, 2017. URL https://ec.europa.eu/transport/sites/ transport/files/c20173711-guidelinesownership-control-carriers.pdf.

[16] EUROPEAN COMMISSION. Commission notice. interpretative guidelines on regulation (ec) no 1008/2008 - public service obligations (pso), 2017. URL https://ec.europa.eu/transport/sites/ transport/files/c20173712-guidelinespso.pdf.

[17] EUROPEAN COMMISSION. Commission staff working document. practices favouring air traffic management service continuity, 2017. URL https://ec.europa.eu/transport/ sites/transport/files/swd20170207practices-favouring-air-trafficmanagement-service-continuity.pdf.

[18] STEER DAVIES GLEAVE. Support study to the ex-post evaluation of directive 2009/12/ec on airport charges, 2017. URL https://publications. europa.eu/en/publication-detail//publication/8e6db69a-e601-11e7-974901 aa75ed71a1/language-en.

[19] EUROPEAN COMMISSION. Public consultation on charges for the use of airport infrastructure, 2017. URL https://ec.europa.eu/info/ consultations/public-consultationcharges-use-airport-infrastructure_ en.

[20] EUROPEAN COMMISSION. Evaluation of regulation 996/2010 on investigating aviation accidents in the eu, 2017. URL https://ec.europa. eu/transport/content/evaluationregulation-9962010-investigatingaviation-accidents-eu_en.

[21] EUROPEAN COMMISSION. Public consultation on the eu air safety list ('black list of air-lines') regulation, 2017. URL https://ec.europa.eu/info/ consultations/public-consultation-euair-safety-list-black-list-airlinesregulation_en. 